\title{
The Effect of Aqueous Extract of Quercus Infectoria on Insulin Resistance and Free Fatty Acids in Insulin-Resistant Rats Induced by a High-Fructose Diet
}

\author{
Hossein Fallah $^{1}$, Behnaz Danesh ${ }^{2}$, Beydolah Shahouzehi ${ }^{3}$, Gholamabbas Mohammadi ${ }^{4}$ \\ 1. Assistant Professor, Department of Clinical Biochemistry, Afzalipour School of Medicine, Kerman University of Medical \\ Sciences, Kerman, Iran. ORCID ID: 0000-0001-6196-0775 \\ 2. Internal Medicine Resident, Department of Internal Medicine, Afzalipour School of Medicine, Kerman University of \\ Medical Sciences, Kerman, Iran. ORCID ID: 0000-0002-3131-0234 \\ 3. Assistant Professor, Physiology Research Center, Kerman University of Medical Sciences, Kerman, Iran. ORCID ID: \\ 0000-0002-8758-6686 \\ 4. Professor, Department of Clinical Biochemistry, Afzalipour School of Medicine, Kerman University of Medical Sciences, \\ Kerman, Iran., (Corresponding Author), Tel: 034-33257448, Email: moghabbas@yahoo.com, ORCID ID: 0000-0002-2621- \\ 0810
}

\begin{abstract}
Background and Aim: Insulin resistance is a pathological condition in which cells fail to respond normally to the insulin. The most important cause of insulin resistance is abdominal obesity. Increased abdominal fat increases the amount of free fatty acids and decreases adiponectin, which directly affects insulin signaling. Due to the role of Quercus infectoria in lowering blood sugar, we investigated the mechanism of action, and the effect of its aqueous extract on insulin resistance in insulin-resistant Rats.

Materials and Methods: The animals were fed fructose-rich or normal food for six weeks. At the end of six weeks, the animals were divided into 4 groups including: receiving plant extracts, pioglitazone, control, and normal food, and then treated for 2 weeks. At the end of the treatment period serum Glucose, triglyceride, and cholesterol levels were measured by autoanalyzer; Insulin, and adiponectin levels were measured by ELISA; plasma free fatty acids were measured by gas chromatography, and HOMA-IR (Homeostatic Model Assessment for Insulin Resistance) index was calculated by the formula. A one-way ANOVA test was used for statistical analysis.
\end{abstract}

Results: In the Quercus infectoria group, the concentrations of glucose $(129.3 \pm 6.8 \mathrm{mg} / \mathrm{dl})$, triglyceride $(79.8 \pm 5.1 \mathrm{mg} / \mathrm{dl})$, insulin $(31.2 \pm 6.32 \mathrm{pmol} / \mathrm{L})$ and HOMA-IR $(1.6 \pm 0.32)$ significantly decreased compared to the control group with glucose $(187.5 \pm 15.9 \mathrm{mg} / \mathrm{dl})$, Triglyceride $(217.6 \pm 18.5$ $\mathrm{mg} / \mathrm{dl})$, Insulin (137.6 $\pm 34.2 \mathrm{pmol} / \mathrm{L})$ and HOMA-IR $(9.7 \pm 2.13)$ decreased. The concentration of total free fatty acids and adiponectin did not change.

Conclusion: This study showed the beneficial effects of aqueous extracts of Quercus infectoria on reducing insulin resistance in insulin-resistant rats.

Keywords: Insulin resistance, Free fatty acids, Pioglitazone, Quercus infectoria Received: Oct 30, $2020 \quad$ Accepted: Nov 21, 2020

How to cite the article: Hossein Fallah, Behnaz Danesh, Beydolah Shahouzehi, Ghilamabbas Mohammadi. The Effect of Aqueous Extract of Quercus Infectoria on Insulin Resistance and Free Fatty Acids in Insulin-Resistant Rats Induced by a High-Fructose Diet. SJKU. 2021;26(1):72-85.

Copyright (C) 2018 the Author (s). Published by Kurdistan University of Medical Sciences. This is an open access article distributed under the terms of the Creative Commons Attribution-Non Commercial License 4.0 (CCBYNC), where it is permissible to download, share, remix, transform, and buildup the work provided it is properly cited. The work cannot be used commercially without permission from the journal 


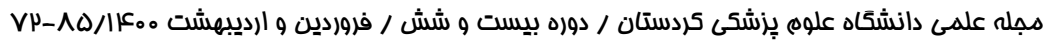

\section{بررسى اثر عصاره آبى مازو (Quercus Infectoria) بر مقاومت انسولينى و اسيدهاى جرب

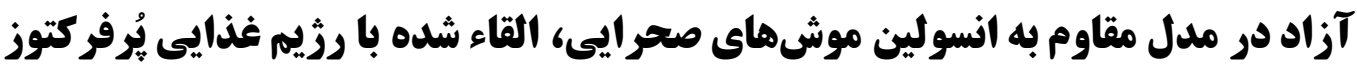

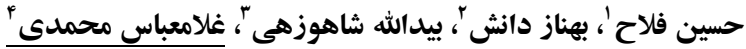

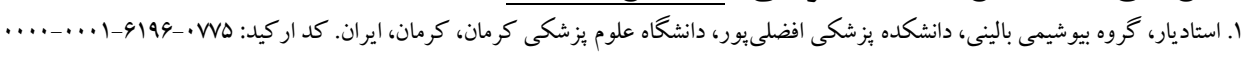

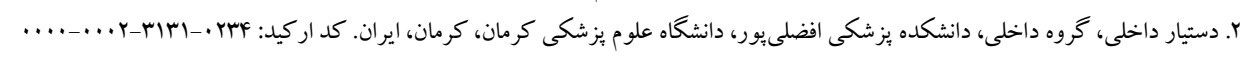

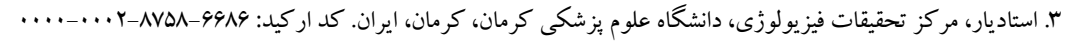

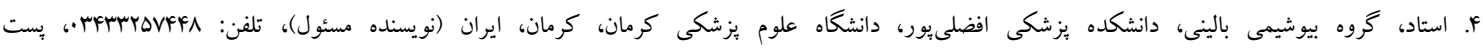

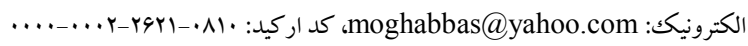

جكيله

زمينه و هدف: مقاومت انسولينى حالتى است كه در آن غلظتهاى نرمال انسولين عملكرد مورد انتظار را ندارد. مهمترين عامل ايجاد مقاومت انسولينى جاقى شكمى است كه باعث افزايش مقدار اسيدهاى خرب آزاد و كاهش آدييونكتين مىشود و مستقيما

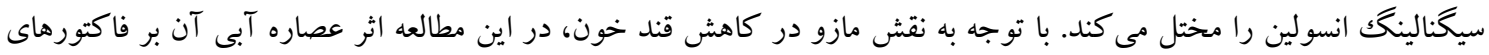

$$
\text { مقاومت انسولينى براى تعيين مكانيسم اثر آن بررسى شد. }
$$

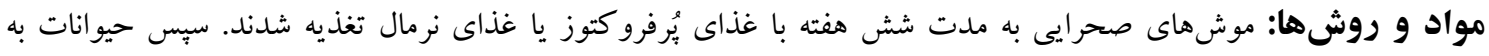

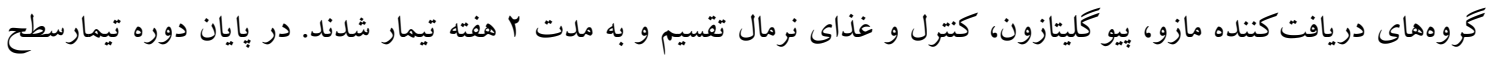

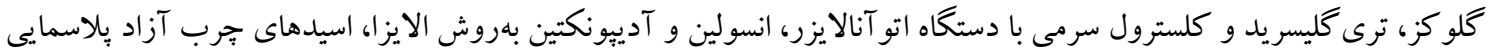

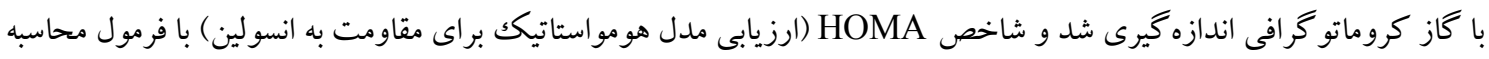

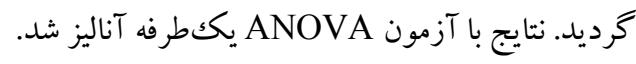

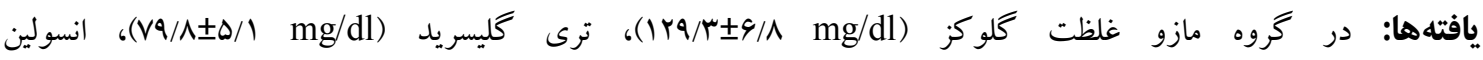

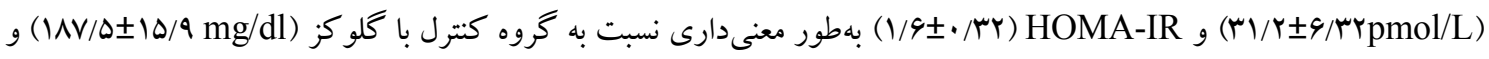

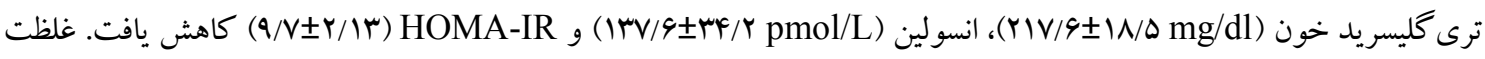

$$
\text { تو تال اسيدهاى جرب آزاد و آدييونكتين تغييرى نشان نداد. }
$$

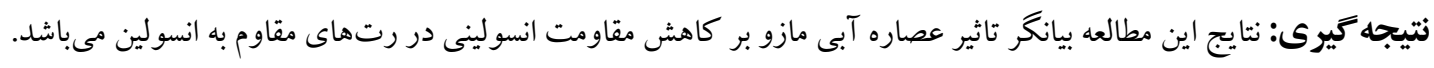

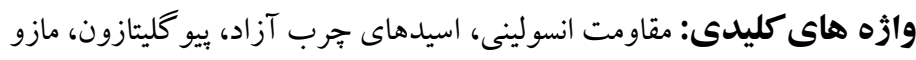


آزاد منجر به افزايش حساسيت به انسولين مى گردد. بهنظر

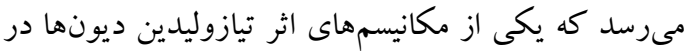
افزايش حساسيت به انسولين، كاهش غلظت اسيدهاى جرب لهاي

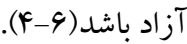

انواع مختلف اسيدهاى جرب بر اساس درجه اشباع و طول زنجيره و از طريق اثر بر رسبتورهاى مختلف اسيدهاى جرب، اثرات متفاوتى را بر عملكرد انسولين و ساير فعاليتهاى متابوليكى اعمال مى كنند. بهعنوان مثال مشخص رات برد شده است كه اسيدهاى جرب زنجيره متوسط و زنجيره بلند

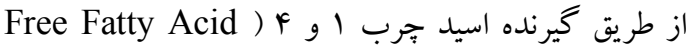
(Receptor, FFAR1,4 در ايجاد مقاومت انسولينى مؤثر هستند، در حالى كه اولئات و اسيدهاى خرب زنجيره كو تاه

مانع از اختلال در سيخنالينگ انسولين مىشود ده (ه). مازو با نام علمى Qercus infectoria متعلق به خانو اده Fagaceae و گياهى درختجهاى است كه در آسياى صغير،

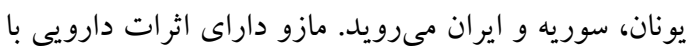
ارزشى است كه مىتوان به خواص منقبض كنندگى

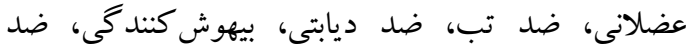
باكتريايى و ضدالتهابى و آنتى اكسيدانى آن اشاره كرد)(V). مطالعات قبلى ما نشان داد كه عصاره آبى مازو داراى اثر

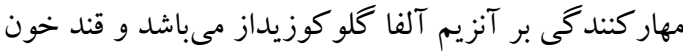

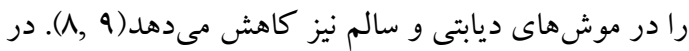

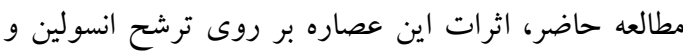
فاكتورهاى دخيل در عملكرد انسولين مانند غلظت آدييونكتين و سطح اسيدهاى جرب آزاد بررسى شدر.

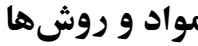

اين مطالعه يكك مطالعه تجربى است كه در آن از موشهاى نر نزاد ويستار استفاده شده است. تهيه عصارهى گياهى:

كالهاى مازو براى تهيه عصاره آبى مورد استفاده قرار

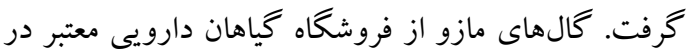

مقدمه

مقاومت انسولينى با هيبرانسولينمى و هيبر كليسمى مشخص

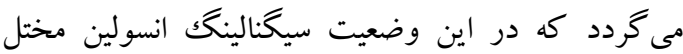
مىشود. اين شرايط با بروز بيمارىهايى مانند ديابت نوع r و و بيمارىهاى قلبى عروقى و كليوى ارتباط دارد( (1). مهمترين فاكتور در ايجاد مقاومت انسولينى جاقى است، كه معمولا داراى دلايل يلى زنتيكى و محيطى است. در سطح مولكولى لئ نيز افزايش فسفريله شدن ريشهاى سرين/ترئونين در Insulin Receptor) سويستراى رسيتور انسولين (Substrate, IRS ديده مىشودكه در نتيجه افزايش فاكتور نكروزى تومور آلفا (Tumor Necrosis Factor $\alpha$, TNFG 4 (Interleukin 6, IL-6) و اسيدهاى جرب آزاد

$$
\text { جلاسمايى صورت مى گيرد (Y). }
$$

آدييوسيتها و ماكروفازهايى كه به اين بافت مهاجرت كردهاند، واسطههاى بيولوزيكى فعالى ترشح مى كنند كه

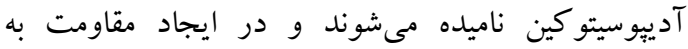
انسولين، ديابت نوع ب و آترواسكلروز نقش دارند. فراوان-

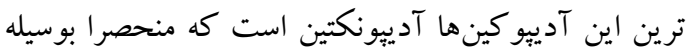
آدييوسيتهاى بالغ ترشح مىشود. آدييونكتين يك آين آدييوسيتو كين ضد التهابى است كه برخلاف بسيارى از آدييو كينها در جاقى كاهش مىيابد و مقدار آن ارتباط

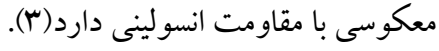
معمولا غلظت بالاى اسيدهاى جرب آزاد، در جاقى و مقاومت انسولينى ديده مىشودكه افزايش غلظت آنها در جاقى در يى عواملى مانند توسعه بافت خربى و افزايش توانايى آزادسازى اسيدهاى جرب آزاد ايجاد مى اسيدهاى خرب آزاد كه با نام اسيدهاى جرب غيراسترى نيز شناخته مىشوند، بهعنوان واسطههاى ايمنى و التهابى از

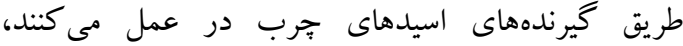
بطوريكه افزايش حاد اسيدهاى جرب آزاد باعث ايجاد مقاومت انسولينى و همجنين كاهش حاد اسيدهاى خرب 
بس از دو هفته حيوانات در هر قفس، شماره گذارى و وزن شدند. از بين آنها 1 حيوان بهطور راندوم بهعنوان گروه

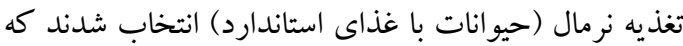
اين گروه در طول دوره تيمار، با غذاى استاندارد و ساير حيوانات با غذاى غنى از فروكتوز تغذيه شدند. تغذيه با

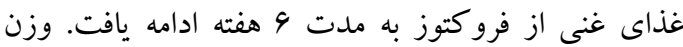
حيوانات در بايان هر هفته اندازهيرى و ثبت شد. بـ از 4 هفته تغذيه با غذاى بر فروكتوز، براى اطمينان از ايجاد مقاومت انسولينى تست تحمل گلوكز بر روى حيوانات

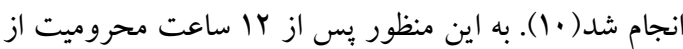
غذا، به ميزان كلو كز بهصورت داخل معدى و با استفاده از

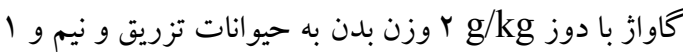

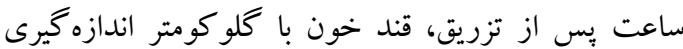
شد(م). سبس حيوانات بهصورت زير تيمار شدند:

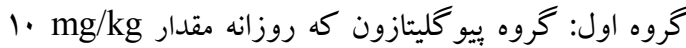

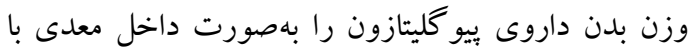
استفاده از كاواز دريافت كردند (كروه ييو كليتازون)(11).

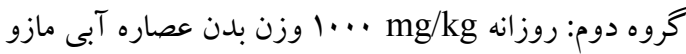
را بهصورت داخل معدى با استفاده از كاواز دريافت كردند

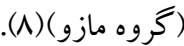
كروه سوم: گروه كنترل مقاوم به انسولين كه هيج دارويى دريافت نكردند (كروه كنترل).

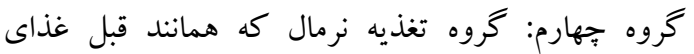
استاندارد مصرف مى كردند (كروه كنترل سالم). غلظت مورد استفادمى عصاره بر اساس مطالعات قبلى ما كه بر روى حيوانات ديابتى شده با استريتوزوتوسين انجام شده بود، تعيين گرديد(^). طول دوره تيمار دارويى دو هفته بوده و دارو و عصارهها بوسيله كاواز به حيوانات خورانده

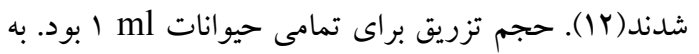

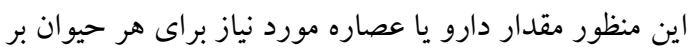

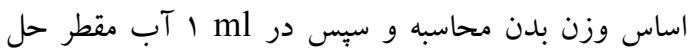

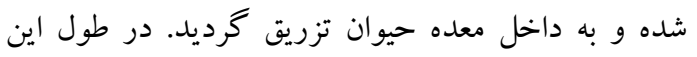

شهر كرمان تهيه و پيس از شناسايى و تأييد توسط گياه شناس، به دقت شسته و سبس در دماى اتاق و در تاريكى تهى تهن خشك شدند. بافتهاى خشك شده گياهان، آسياب و

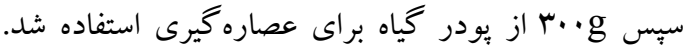
بدين ترتيب كه g.r. يودر گياه را در يك ارلن ريخته و

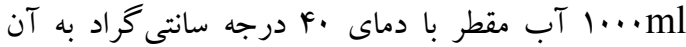

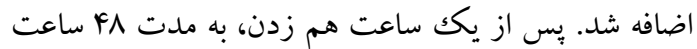
در دماى اتاق و در تاريكى نخهدارى شد. سبس محلول

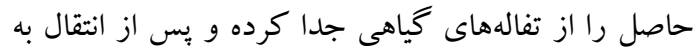

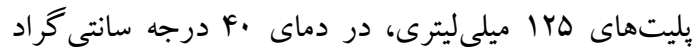
درون آون خشك شد. عصاره گياهى خشك شده از

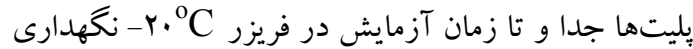

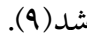

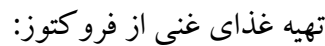

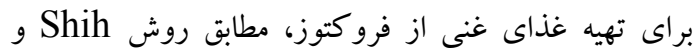

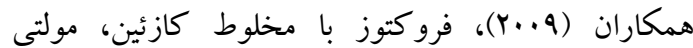

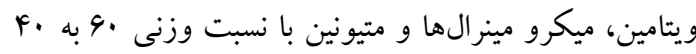
مخلوط و با افزودن مقدار كمى آب مقطر بهصورت خمير در آمد. اين خمير به شكل بلتهاى استاندارد در آمده و سِّ در مجاورت هوا خشك شد. غذا تا زمان مصرف در

يخجال نخهارى شد •(1).

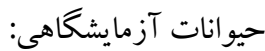

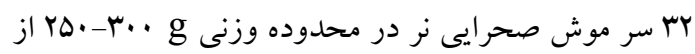
حيوانخانه دانشكده يزشكى دانشكاه علوم يز شكى كرمان خريدارى شد. حيوانات به اتاقى جداكانه در حيوانخانه منتقل و بهطور راندوم در قفسهاى بأ تايى تقسيم شدند. جهت ساز كارى با محيط جديد، حيوانات بهمدت Y هفته در اين اتاق نخهدارى شدند. دماى اتاق به و و داراى شرايط

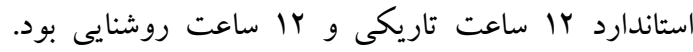

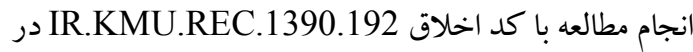
كميته اخلاق دانشگاه علوم بز شكى كرمان به تصويب رسيده

هبله علمى دانشكاه علوم بِرشكى كردستان / دوره بيست و شش / فرودين و ا(ديبرشت م.ع|| 
استاندارد داخلى، انجام شد(سا). ابتدا جربىها از ساير

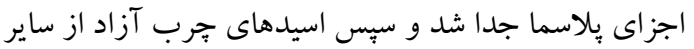
لييدها با كروماتو گرافى لايه نازك جدا گرديد. در نهايت از اسيدهاى جرب مشتق متيل استر تهيه و جهت آناليز به دستخاه كروماتو گرافى گاز تزريق شد.

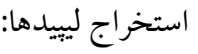

براى استخراج ليييدها از يلاسما از معرف Dole (ايزويرويانول-هيتان-اسيد كلريدريك ( IM) با نسبت حجمى به ترتيب ·f به ·ل به () استفاده شد. بدين ترتيب كه

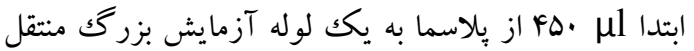
شerck, ) شه و بl •ه ينتا دكانوئيك اسيد (Img/ml Dole به آن افزوده شد. سيس Fermany به آن افزوده و بهمدت ·r دوقيقه به شدت ورتكس شد. پس از آن لوله آزمايش به مدت • ا دقيقه در دماى اتاق انكوبه و

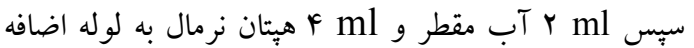
شد. مجددا لوله به مدت ه دقيقه ورتكس و سֶس به مدت

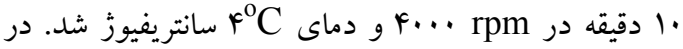
انتها فاز رويى (هيتان) كه حاوى تمامى اجزاى ليبيدى يلاسماست، جداو حلال آن در دماى C C F تبخير شد. جداسازى اسيدهاى جرب: براى جداسازى اسيدهاى جرب آزاد از ساير ليِيدها از

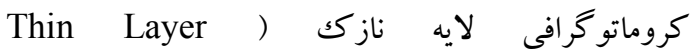
(Chromatography, TLC استفاده شد. به اين منظور: به له فاز ليبيدى جدا شده در مرحله قبل هml/·كلروفرم افزوده شد و سبس تمامى هml/• نمونه روى نقاط مجاور هم بر

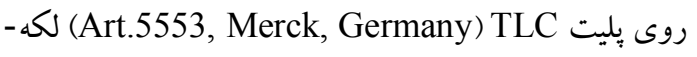
كذارى شد. فاز متحرك تر كيب حلال هيتان-دى اتيل اتر -

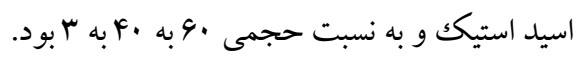

براى تشخيص موقعيت باندها بر روى صفحه TLC از يد

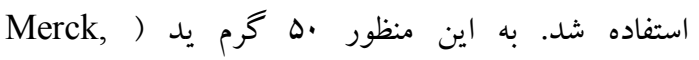

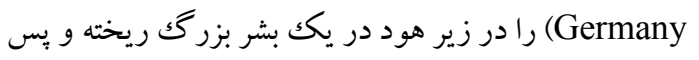
از قرار دادن صفحه TLC درون بشر، دهانه آن با فويل آلومينيومى بسته شد. باند اسيدهاى جرب آزاد در مقايسه با
مدت، وزن حيوانات بهصورت هفتخى و ميز ان مصرف آب و غذاى آنها بهصورت روزانه اندازه گيرى و ثبت شد.

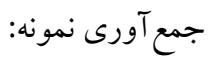
بس از يايان دوره تيمار دو هفتهاى، نمونه كيرى از حيوانات انجام شد. تمامى نمونه گيرىها در صبح و يس از با ساعت محروميت از غذا صورت گرفت. در زمان نمونه گيرى، تزريق دارو يا عصاره گياهى به حيوانات انجام نشد. جهت نمونه گيرى، ابتدا حيوان با اتر بيهوش شد و بس از خونگيرى از قلب، نمونه خون در دو لوله مجزا (يكى دارا و ديخرى فاقد ضد انعقاد EDTA Ethylenediaminetetraacetic, جمع آورى شد. نمونههاى خون تا زمان جداسازى (acid سرم و يّلاسما روى يخخ قرار داده شدند. بهمنظور جداسازى سرم يا پِاسما، نمونهاى خون در دماى

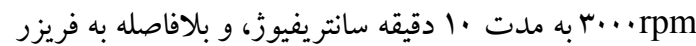
- VD ${ }^{\mathrm{O}} \mathrm{C}$ اندازه گيرى فاكتورهاى بيوشيميايى: اندازه گيرى غلظت هاى كلوكز، ترى كليسريد، كلسترول و HDL-c شركت يارس آزمون) در آزمايشگاه رازى كرمان و توسط دستخاه اتو آنالايزر ل... RA-1 انجام شد. اندازه گيرى غلظت انسولين و آديبونكتين: با استفاده از كيتهاى الايزاى اختصاصى انسولين رت ) CEA448Ra, SEA605Ra, ) و آدييونكتين رت (USCN, China و دقيقا مطابق دستورالعمل كيت، مقادير (USCN, China انسولين و آدييونكتين اندازهيرى شدند. حساسيت كيت

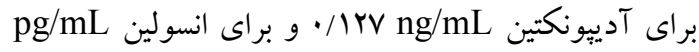

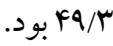
ستو محاسبه HOMA-IR با استفاده از فرمول HOMA - IR $=\frac{\text { glucose }(\mathrm{mmol} / \mathrm{L}) \cdot \operatorname{insulin}(\mu \mathrm{U} / \mathrm{ml})}{22.5}$ اندازه خيرى شد.

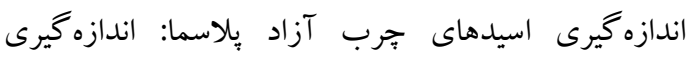
اسيدهاى جرب پِاسمايى بر اساس روش Kangani و

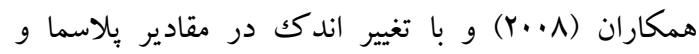


تا بايان كار حفظ شد. دماى آون به مدت ا دقيقه بر روى

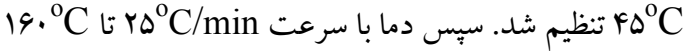
و سبس با سرعت 190 افز ايش يافت و

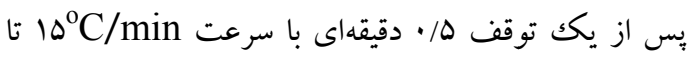

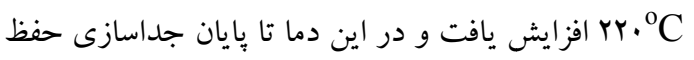
شد. دتكتور FID نيز داراى دماى Co

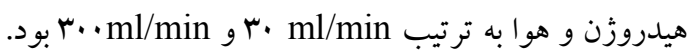

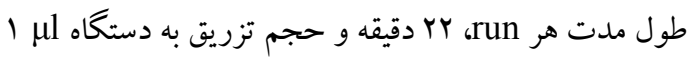

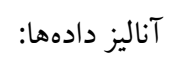

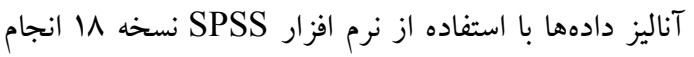

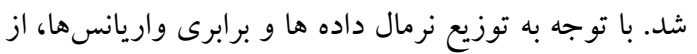
تست ANOVA يك طرفه براى آناليز استفاده شد. همجنين جهت تغييرات در بين گروهها با آزمون Tukey Post Hoc P تعيين گرديد. نتايج بهصورت Mean كمتر از هـ/• Value

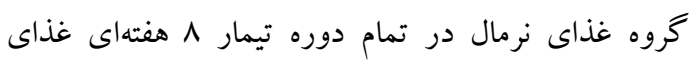

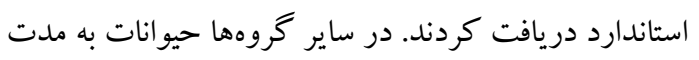
4 هفته با غذاى غنى از فروكتوز تغذيه شدند و بساز اين

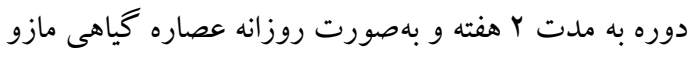
يا بيو گليتازون (1...mg/kg)

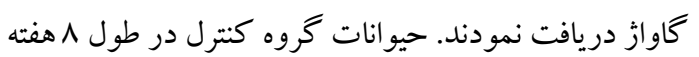
با غذاى غنى از فرو كتوز و بدون هيج دارويى تغذيه شدند

.$(n=\wedge)$
استاندارد اسيد جرب، از روى صفحه TLC تراشيده و پِ

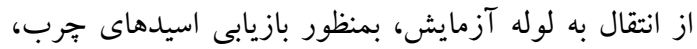

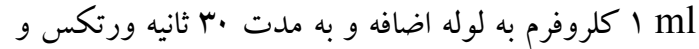

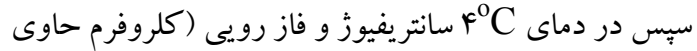
اسيدهاى جرب) جداو در آون f. C كاملا تبخير شد. تهيه مشتق متيل استر اسيدهاى جرب: تهيه مشتق متيل استر اسيدهاى جرب با استفاده از محلول (B1252, Sigma, USA) (Trifluoride Boron) BF3 در متانول صورت گرفت. به اين صورت كه به لوله حاوى اسيدهاى خرب مرحله قبل، 1 ml محلول BF3 در متانول (أl\%) افزوده و در لوله بسته شد. محلول به شدت هم زده شده و به مدت اه ساعت در دماى $1 /{ }^{\circ}$ مقرار داده شد.

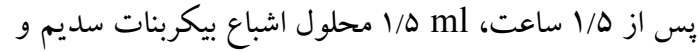

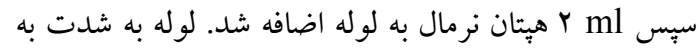
مدت r دقيقه ورتكس و سبس به مدت r دقيقه در

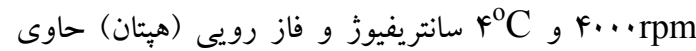
Free Fatty Acid Metyl ( متيل استرهاى اسيد جرب (Ester ,FAME) جدا شد. هبتان تا حجم هml/•در آون (Agilent, 7890A, USA) GC تبخير و سبس به دستگاه تزريق شد. كروماتو گرافى گاز: دماى inlet بر روى

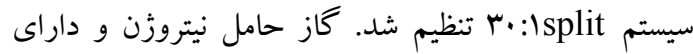
شيب فشارى psi •r به مدت ^ دقيقه و سبس افزايش فشار

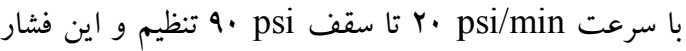

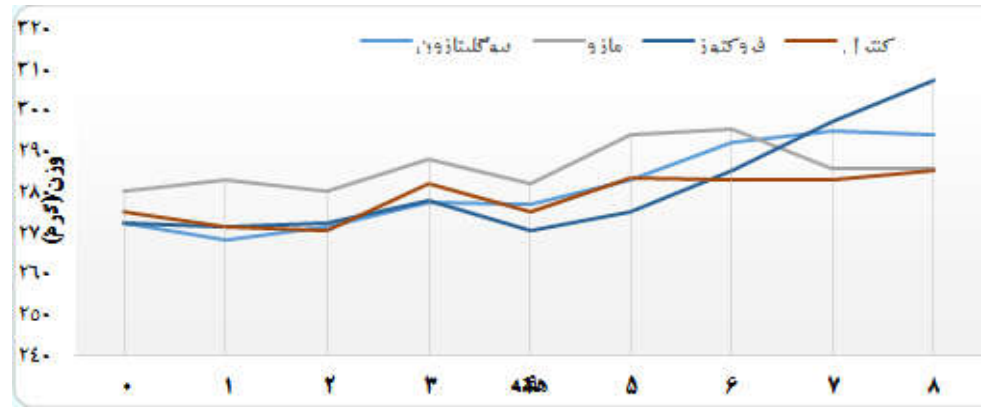

نمودار ا. تغيير وزن حيوانات كروه تيمار شده با عصاره آبى Fال هاى مازو در مقايسه با كروههاى كنترل، بيو Fليتازون و غذاى نرمال

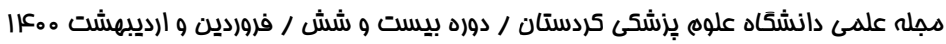




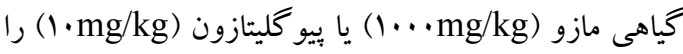
بهوسيله كاواز دريافت نمودند. حيوانات گروه كنترل در طول 1 هفته با غذاى غنى از فروكتوز و بدون هيج دارويى تغذيه شدند (n=人).
حيوانات گروه غذاى نرمال در تمام دوره تيمار ^ هفتهاى غذاى استاندارد دريافت كردند. در ساير گروهها حيوانات به مدت 9 هفته با غذاى غنى از فرو كتوز تغذيه شدند و يس از اين دوره به مدت r هفته و بهصورت روزانه عصاره

جدول ا. ميزان مصرف روزانه آب و غذاى حيوانات در نتيجه تيمار با عصاره آبى كال هاى مازو

\begin{tabular}{|c|c|c|c|c|c|c|c|}
\hline \multicolumn{4}{|c|}{ آب مصرفى (ml/day) } & \multicolumn{4}{|c|}{ غذاى مصرفى (g/day) } \\
\hline كنترل & غذاى نرمال & بيو كليتازون & مازو & كنترل & غذاى نرمال & بيو كليتازون & مازو \\
\hline$F V / I \pm \Lambda / \cdot F$ & $r \Delta / \cdot \pm \Delta / \Lambda r$ & $9 \cdot / r \pm 1$ & $\Delta r / Y \pm \Delta / 1$ & $\mid r / \cdot \pm r / r q$ & $r Y / \cdot \pm r / \Delta r$ & $\mid r / \cdot \pm r / r \Delta$ & $\mid r / \cdot \pm V / r \Delta$ \\
\hline $\mathrm{P}$ value & $\cdot / \cdots 1$ & $\cdot / \cdots 1$ & $\cdot / A \cdot r$ & $\mathrm{P}$ value & $>\cdot / \cdots \cdot 1$ & 1 &.$/ 949$ \\
\hline
\end{tabular}
كزارش شده، اختلاف با گروه كنترل را نشان مىدهد P value

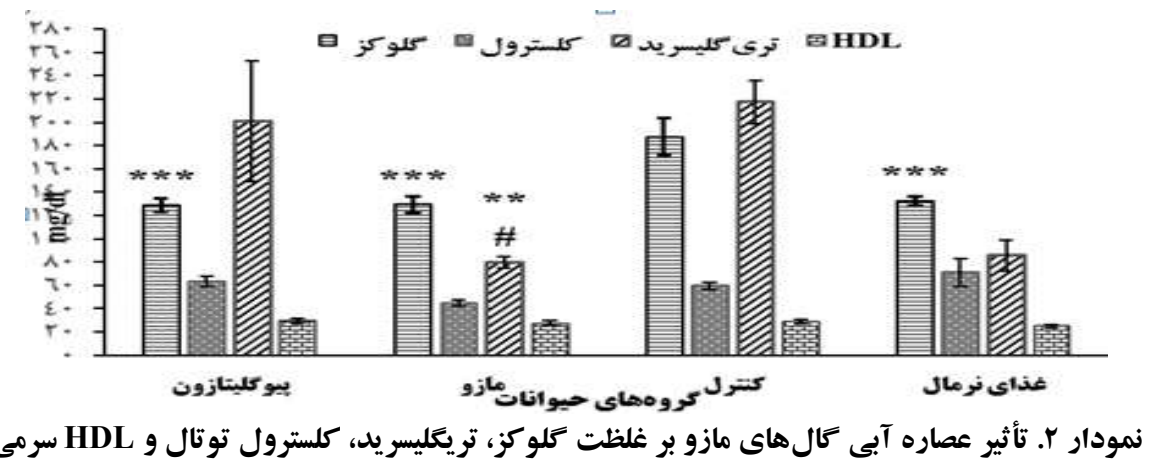

طول م هفته با غذاى غنى از فرو كتوز و بدون هيج دارويى تغذيه شدند. تمامى فاكتورها در نمونه سرمى و به روش آنزيمى و بعد از rا ساعت ناشتايى اندازه گيرى شده است (n=人) شده است و با آزمون ANOVA يككطرفه آناليز شدهاند و

$$
\text { ه • • معنى دار در نظر كرفته شده است. }
$$

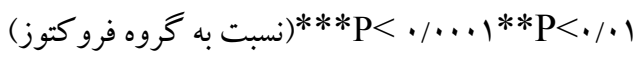

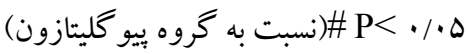

جدول r. تأثير عصاره آبى كالهاى مازو بر غلظت انسولين، آدييونكتين و شاخص HOMA-IR

\begin{tabular}{|c|c|c|c|c|c|}
\hline P value & ي ييو كليتازون & 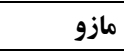 & كنترل & غذاى نرمال & \\
\hline$>\cdot / \cdots 1$ & $F \cdot / r \pm r / V Q$ & $r / / 9 \pm r / \mu r$ & $1 r V / r F \pm 9 / r$ & $\Delta \cdot / f \pm \Delta / \Lambda$ & غلظت انسولين (pmol/l) \\
\hline.$/ 94$ & $\Delta / \pm \pm q / Y q$ & $r / \cdot \pm \Delta q / r$ & $r / \cdot \pm \lambda 9 / / f$ & $r / \cdot \pm q / / f$ & غلظت آدييونكتين (ng/ml) \\
\hline$>\cdot / \cdots \cdot 1$ & $r / \cdot \pm \| 1 / / r$ & $1 / . \pm 9 / \pi Y$ & $Q / Y \pm V / T r$ & $r / \pm V V / \mu \Lambda$ & HOMA-IR \\
\hline
\end{tabular}


طول ^ هفته با غذاى غنى از فرو كتوز و بدون هيج دارويى

تغذيه شدند. هورمونها در نمونه سرمى و بعد از با ساعت

ناشتايى به روش الايزا و HOMA با فرمول محاسبه شد

(n=人)

شده است و با آزمون ANOVA يككطرفه آناليز شدهاند و

ه< Pعنى Pارد در نظر گرفته شده است (جدول Y).
حيوانات گروه غذاى نرمال در تمام دوره تيمار ^ هفتهاى غذاى استاندارد دريافت مى كردند. در ساير گروهها حيوانات بهمدت 9 هفته با غذاى غنى از فروكتوز تغذيه شدند و يس از اين دوره بهمدت r هفته و بهصورت روزانه

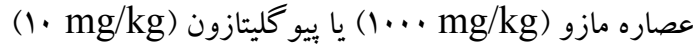
را بهوسيله گاواز دريافت نمودند. حيوانات گروه كنترل در

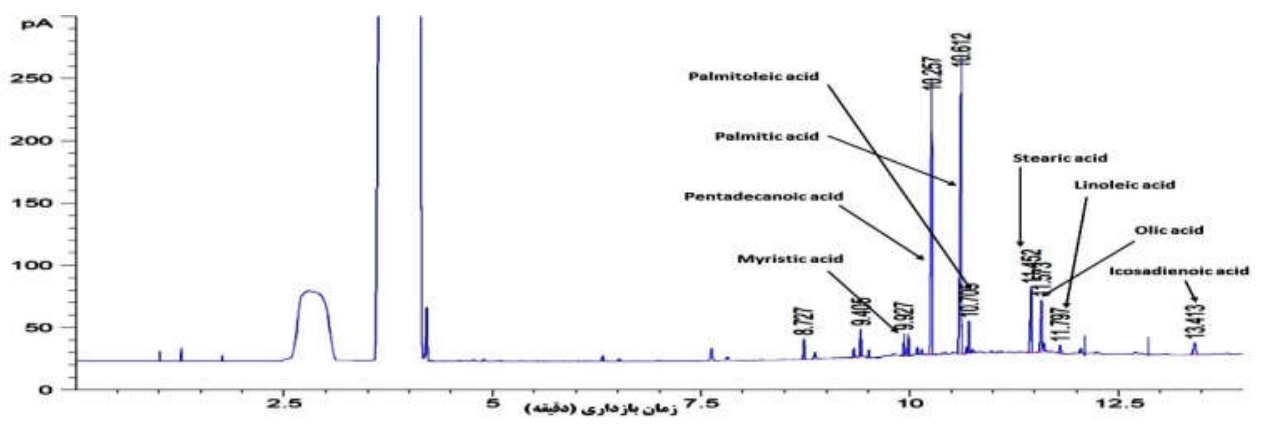

شكل ا. نمونه كروماتوكرام اسيدهاى جرب آزاد در حيوانات تيمار شده عصاره مازو

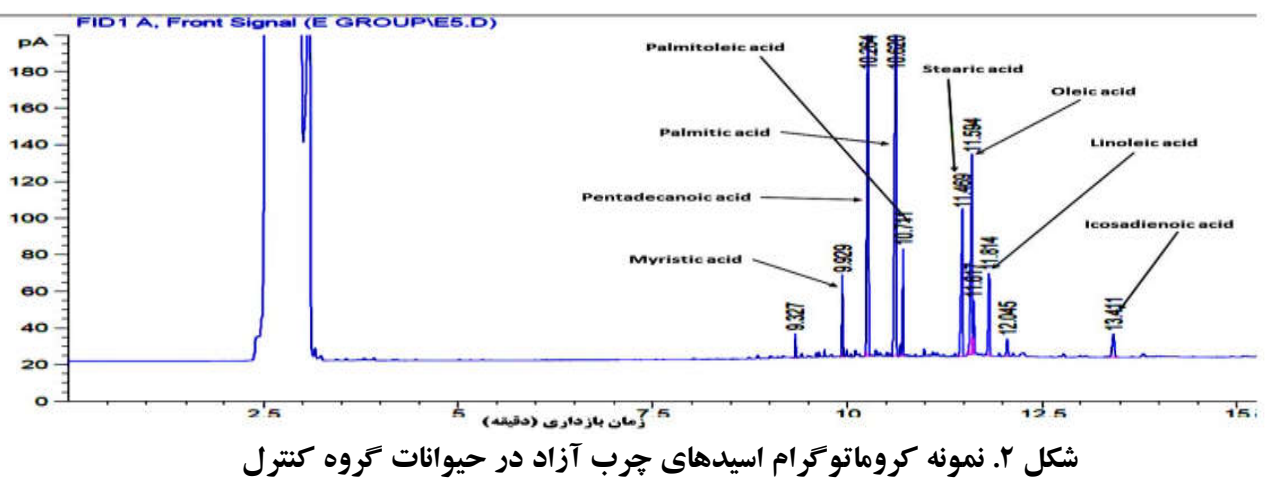

تغذيه شدند. اسيدهاى جرب آزاد در نمونه يّاسمايى و بعد از إ ساعت ناشتايى به روش كروماتو گرافى كاز اندازهـ-

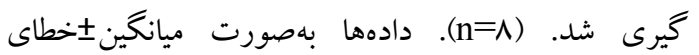

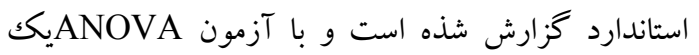
طرفه آناليز شده اند و ه •/ P معنى Pارد در نظر كرفته شده

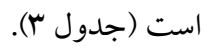

حيوانات گروه غذاى نرمال در تمام دوره تيمار ^ هفتهاى غذاى استاندارد دريافت مى كردند. در ساير كروهها حيوانات بهمدت 4 هفته با غذاى غنى از فروكتوز تغذيه شدند و بس از اين دوره به مدت r هفته و بهصورت روزانه

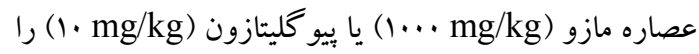
بهوسيله گاواز دريافت نمودند. حيوانات گروه كنترل در طول ^ هفته با غذاى غنى از فروكتوز و بدون هيج دارويى سيى

هبله علمى دانشكاه علوم بِرشكى كردستان / دوره بيست و شش / فرودين و ا(ديبرشت م.ع|| 
در مقايسه با گروه كنترل ه ه

جدول r. تأثير عصاره مازو بر يروفيل اسيدهاى جرب آزاد يالاسمايى در مقايسه با كروه فروكتوز و ييو كليتازون

\begin{tabular}{|c|c|c|c|c|}
\hline ي ي ي كليتازون & 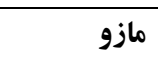 & كنترل & غذاى نرمال & اoو \\
\hline $1 / \cdot \pm \Delta \cdot \Delta / \cdot \Delta$ & I/EIIY/.r & $1 / \cdot \pm 11 / 1$ & $1 / \cdot \pm F r / \cdot \Delta$ & د كانوئيك اسيد (رmol/L) \\
\hline $1 / \cdot \pm 1 \wedge / \Gamma$ & $\cdot / \cdot \pm 9 V / 11$ & $1 / \cdot \pm \cdot \Lambda / \cdot 1$ & $\cdot / \cdot \pm q F / \cdot V$ & لائوريك اسيد (رmol/L) \\
\hline $1 / \cdot \pm r F / \cdot 9$ & $1 / \cdot \pm r \Lambda / \cdot 9$ & $1 / \cdot \pm 1 \cdot / \cdot V$ & $1 / \cdot \pm \cdot V / \cdot r$ & مير يستيك اسيد (رmol/L) \\
\hline$\Delta / \cdot \pm \backslash \Lambda / \backslash \Lambda^{* * *}$ & $\Lambda / \pm E r / r \Lambda^{*}$ & $11 / r \pm 19 / 9 r$ & $\Delta / \cdot \pm q \mathrm{~V} / \Delta \mathrm{V} * * *$ & يالميتيك اسيد (بmol/L) \\
\hline $1 / \cdot \pm 1 \cdot / \cdot 1$ & $1 / \cdot \pm v 9 / 19$ & $1 / \cdot \pm F V / I r$ & $1 / \cdot \pm \cdot 9 / 1 \mathrm{~F}$ & يالميتولئيك اسيد (رmol/L) \\
\hline$r / \cdot \pm \cdot 9 / 1 r$ & $r / \cdot \pm \wedge r / M I$ & $r / \cdot \pm V r / I r$ & $r / \cdot \pm r \Delta / 1 r$ & استئاريكك اسيد (رmol/L) \\
\hline $1 / \cdot \pm V Y / \cdot 9 * *$ & $r / \cdot \pm \wedge \varepsilon / \mu r$ & $r / \cdot \pm Q Y / Y r$ & $r / \cdot \pm r \cdot / r^{*} * *$ & اولئيك اسيد (بmol/L) \\
\hline$r / . \pm \Delta \Lambda / \Gamma \mu * *$ & $1 / \cdot \pm 94 / r$ & $1 / \cdot \pm F \Delta / I r$ & $r / \cdot \pm r Y / \cdot 9^{*}$ & ايكوزا دى انوئيك اسيد (رmol/L) \\
\hline$|V / I \pm 19 / 1|^{* * *}$ & $r \mid / I \pm r r / \Delta l$ & $r Y / Y \pm q \Lambda / V Y$ & $\mid V / \cdot \pm r q / V r^{* *}$ & اسيد جرب آزاد توتال (رmol/L) \\
\hline
\end{tabular}

هيج اختلاف معنىدارى را نشان نداد. وزن حيوانات در

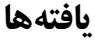

هفتهاى اول تا هشتم نيز اختلاف معنىدارى نداشت. وزن

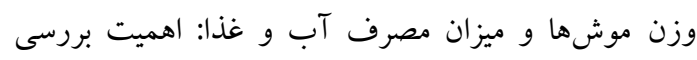

g) هفته هشتم در گروه كنترل (r) تغييرات وزنى حيوانات همراه با ميزان مصرف آب و غذا در

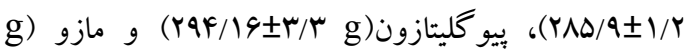

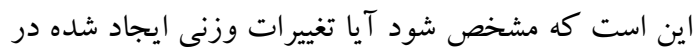

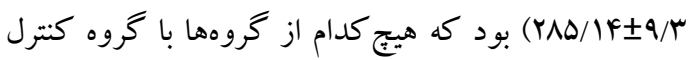

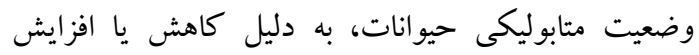
اختلاف معنىدارى را نشان نداد. اما ميزان افزايش وزن حيوانات در طول هشت هفته، كه از اختلاف وزن هفته

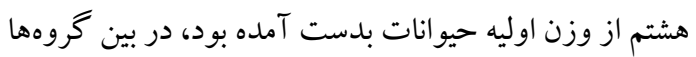

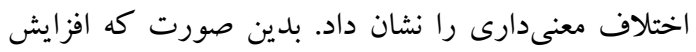

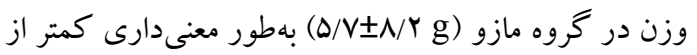
كروه فروكتوز ( در نتيجه مصرف غذاى بر فروكتوز جلو گيرى كرد. روند تغييرات وزن حيوانات در نمودار شماره ا نشان داده شده

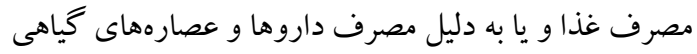
بوده است. هيج اختلاف معنىدارى از نظر ميزان مصرف

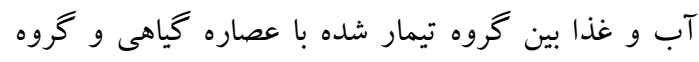

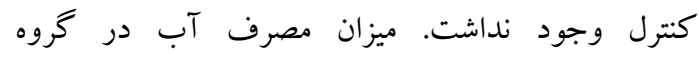

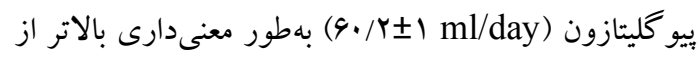

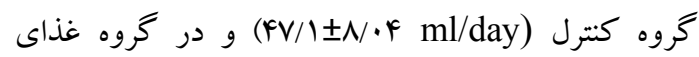

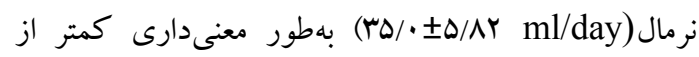

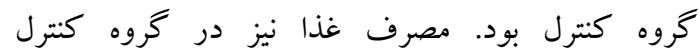

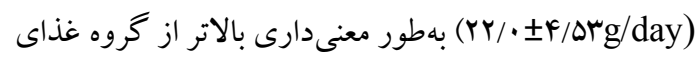
فاكتورهاى بيوشيميايى سرم: ميزان كلوكز سرمى در گروه

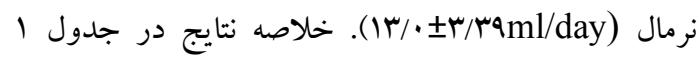

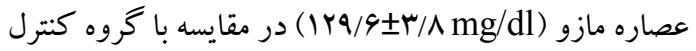

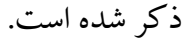

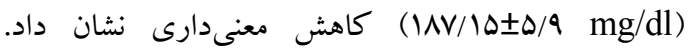
وزن حيوانات: وزن اوليه حيوانات، كه قبل از آغاز مصرف اختلاف معنىدارى بين ميزان كلوكز ناشتا در نتيجه مصرف اين عصاره با كروه غذاى نرمال (

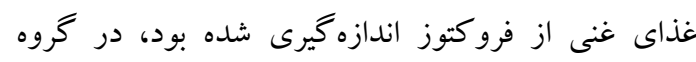
كنترل (Y)

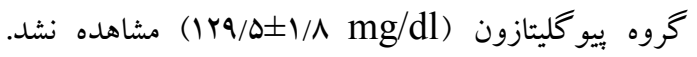
ييو گليتازون 
معنى دارى در HOMA.IR بين گروههاى تيمار شده با

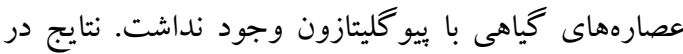
جدول شماره Y خلاصه شده است. غلظت اسيدهاى جرب آزاد:

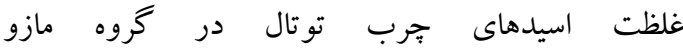
يبيو گليتازون

( $(Y) / \perp \pm M / \Delta) \mu \mathrm{mol} / \mathrm{L})$

غذاى 9

$(I V / I \pm q / I F \mu \mathrm{mol} / \mathrm{L})$

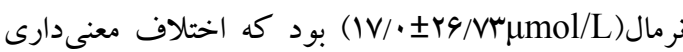

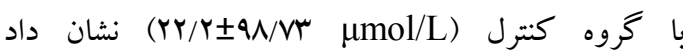

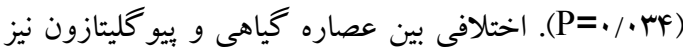
از نظر اثر بر غلظت اسيدجرب توتال مشاهده شد. در بين بين

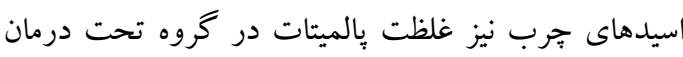
با عصاره مازو اختلاف معنىدارى با گروه كنترل نشان داد.

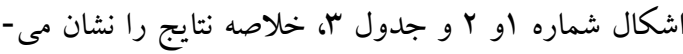

دهد.

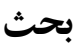

از نظر كلينيكى مقاومت انسولينى با افزايش مزمن غلظت كلوكز و انسولين مشخص مىشود كه علت آن كاهش

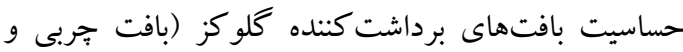
عضلانى) به غلظت بالاى انسولين موجود در خردش خون برد

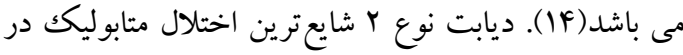

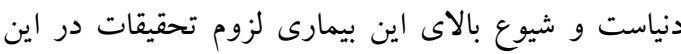

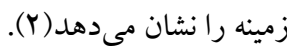

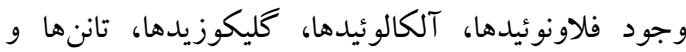
تركيبات فنولى باعث مىشود كه گياهان اثرات آنتى ديابتيك متفاوتى اعمال كنند(ها). در اين مطالعه اثر عصاره كياهان مازو بر فاكتورهاى مقاومت انسولينى در رتهاى مقاوم به انسولين بررسى شد. مقاومت انسولينى ايجاد شده در رت كه در اين مطالعه نيز مورد استفاده قرار گرفت، در

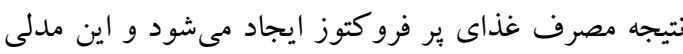
است كه بهطور رايج براى مطالعات مورد استفاده قرار mg/dl) ميزان ترى كليسريد خون در گروه مازو

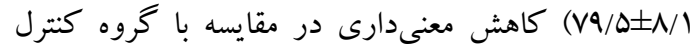
نشان داد. ميزان كاهش ترى (YIV/MA كليسريد بوسيله عصارههاى مازو در مقايسه با بيو كليتازون

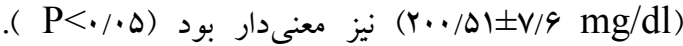
وييو كليتازون بر خلاف عصاره مازو تأثير معنىدارى بر ميزان ترى كليسريد خون در مقايسه با گروه كنترل نداشت.غلظت كلسترول توتال در گروه مازو (D)/ تفاوت معنىدارى با گروه كنترل(ه/ ي يو كليتازون ( كلسترول خون در گروه كنترل و غذاى نرمال(mg/dl

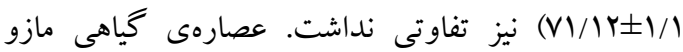

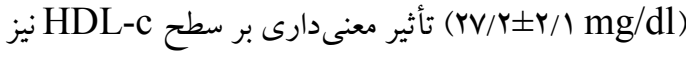
در مقايسه با گروه كنترل (ra//

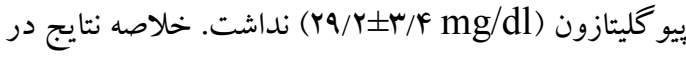
نمو دار شماره r نشان داده شده است. سطح سرمى انسولين و آدييونكتين:

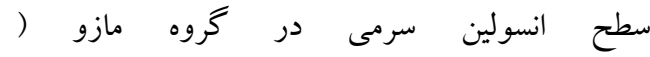

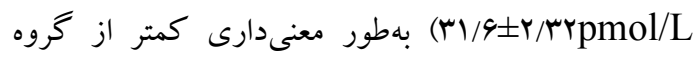
كنترل (IrV/MF بين سطح انسولين در گروه دريافت كننده عصارهى گياهى

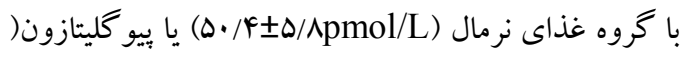

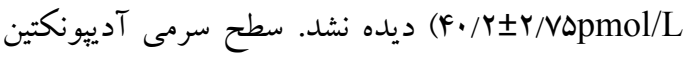
در گروه دريافت كننده عصاره مازو (F/• نسبت به گروه كنترل (

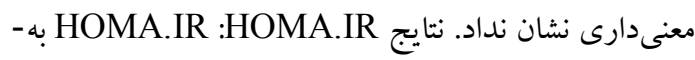
عنوان شاخص اندازه گيرى مقاومت انسولينى در عصاره

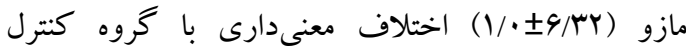

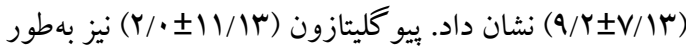
معنىدارى باعث كاهش HOMA.IR در حيوانات شد. نتايج نشان داد كه اين عصاره اثر معنىدارى بر كاهش باهُ HOMA 
Ap

HOMA-) HOMA.AD و (of $\beta$-cell function براى بررسى وضعيت حساسيت به انسولين Adiponectin

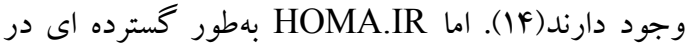

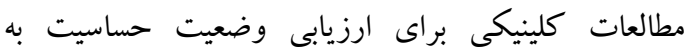

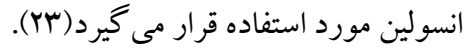
ترشح انسولين بهوسيله فاكتورهاى متعددى كنترل مى شود دود ولى مهمترين سيكنال تحريك ترشح انسولين، افزايش مقدار كلوكز است كه در مصرف غذاهاى يركربوهيدرات رخ مىدهد و به آن ترشح انسولين تحريككشده بهوسيله كلو كز (Glucose Stimulated Insulin Secretion, GSIS) كفته مىشود(YF). احتمالا عصارمى مازو از طريق كاهش كلو كز خون(A)، باعث كاهش كلو كز به كمتر از حد آستانه و برداشته شدن اثر GSIS و در نتيجه كاهش ترشح انسولين مىشوند(Y)). كاهش HOMA.IR و كَلوكز خون، همراه با كاهش سطح انسولين نشاندهنده افزايش عملكرد انسولين بجاى افزايش ترشح انسولين مىباشد كه ممكن است مربوط

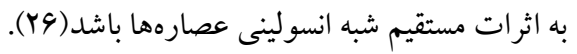

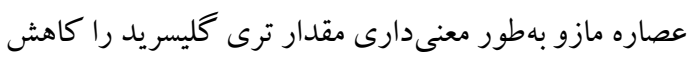

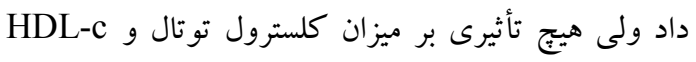
نداشت. در مطالعه Gholamhosseinian و هم همكاران

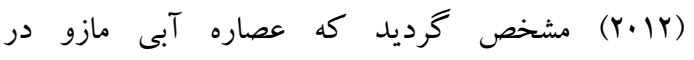

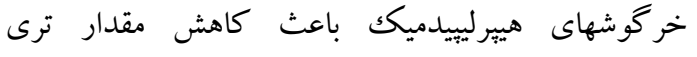

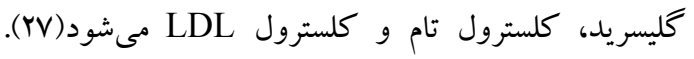
نتايج بهدست آمده از عصاره مازو با مطالعه ما همخوانى

هييرترى كليسريدمى و افزايش توليد VLDL

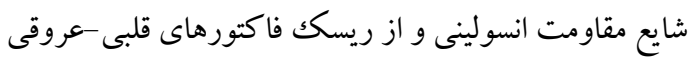
محسوب مىشوند. راهنماى Adult treatment ) ATPIII تو صيه مى كند درمانهايى كه منجر به كاهش راه ترى كليسريد و كلسترول LDL و همجينين افزايش كلسترول HDL مى گردند، در سندروم متابوليك بايد مورد

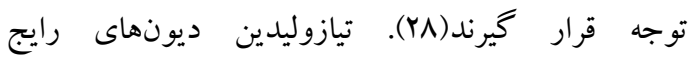

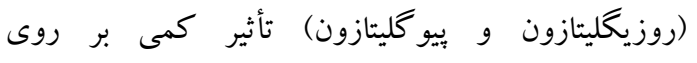

مى گيرد و بخوبى شرايط مقاومت انسولينى در انسان را تقليد مى كند (19).

با توجه به اينكه جاقى و يرخورى فاكتورهاى خطر مهمى براى مقاومت انسولينى محسوب مىشود، وزن حيوانات و نيز مصرف آب و غذاى آنها در اين مطالعه مورد ارزيابى

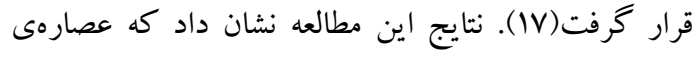

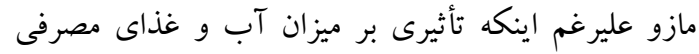

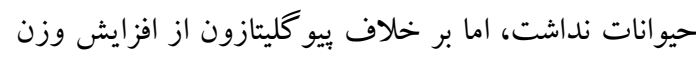
حيوانات در مقايسه با گروه فروكتوز جلو گيرى كرد.

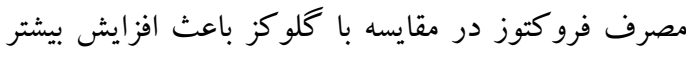
ذخيره جربى احشايى مى شود و در ايجاد مقاومت به انسولين

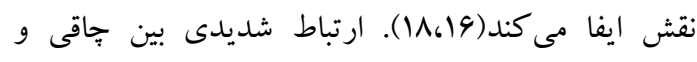
مقاومت انسولينى وجود دارد و در جاقى و افزايش تودهـ جربى، توليد سيتو كينهايى افزايش مى يابد كه باعث ايجاد

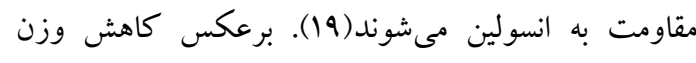

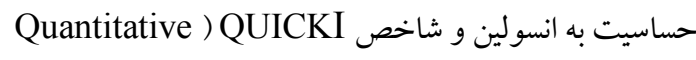
(insulin check index

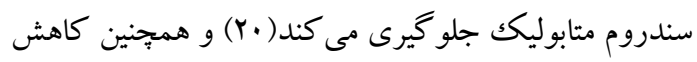
وزن و ورزش، حتى در مصرف رزيم غنى از كربوهيدرات

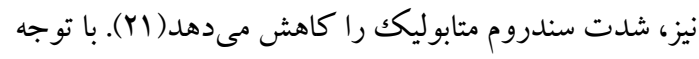
به شواهد فوق مى توان اظهار داشت كه احتمالا عصاره ى

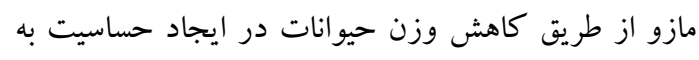
انسولين مؤثر واقع مى مازود. عصاره متانولى ريشه مازو باعث كاهش معنى والع مدود مارد كلوكز

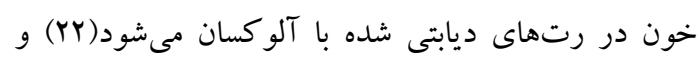

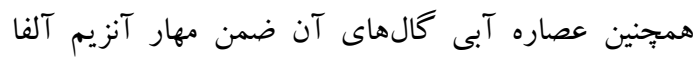

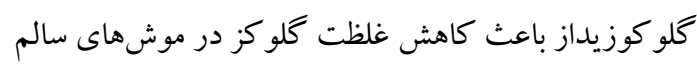

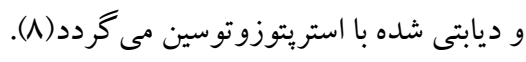

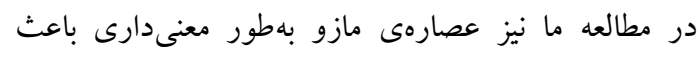

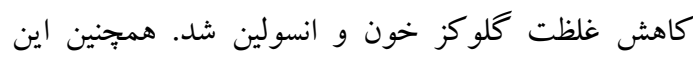

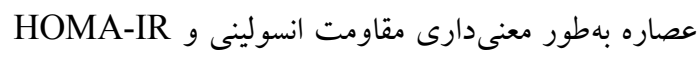

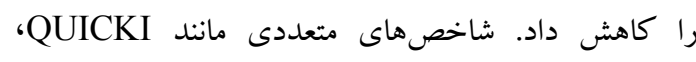
The homeostasis model assessment ) HOMA. $\beta$ 
مقاومت انسولينى يكك وضعيت بِيجِيده متابوليكى است كه با كاهش عملكرد انسولين در بافتها و در نتيجه، افزايش غلظت انسولين، كلوكز، ترى كليسريد، كاهش HDL-c، افزايش اسيدهاى جرب آزاد و كاهش آدييونكتين مشخص تافي

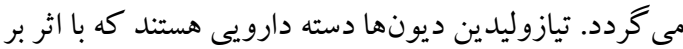

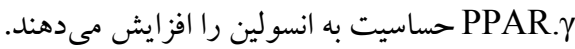

\section{تتيجه كيرى}

مطالعه حاضر نشان داد كه عصاره مازو موجب افزايش حساسيت به انسولين در موشهاى مبتلا به مقاومت انسولينى در نتيجه يكك رزيم يرفروكتوز مىشود. از آنجا كه اين عصاره تأثيرى بر ترشح آدييونكتين بهعنوان يك بك آدييو كين حساس كننده به انسولين و سطح اسيدهاى جرب آزاد براد بِلاسمايى ندارد، بنابراين اين عصاره احتمالا اثرات افزايش حساسيت انسولينى را از طريق ساير فاكتورهاى دخيل در اين

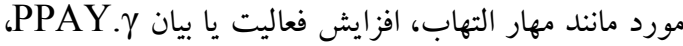
افزايش انتقال كلوكز ترانسيورتر f به سطح غشا انجام مىشود. بنابراين در نظر داريم در مطالعات تكميلى موارد

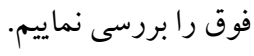

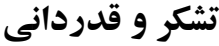

اين طرح با كد اخلاق IR.KMU.REC.1390.92 سدرداب كميته اخلاق دانشگاه علوم يزشكى كرمان به تصويب رسيده و هزينه انجام آن طبق قرارداد .../.9 توسط معاونت يُزوهشى دانشگاه علوم يزشكى كرمان تامين و تمامى مراحل مطالعه در گروه بيوشيمى دانشكده بز شكى افضلى بور و در دانشگًاه علوم يزشكى كرمان انجام شده است. نويسند كان از تمامى يارى دهند كان انجام اين مطالعه كمال قدردانى و

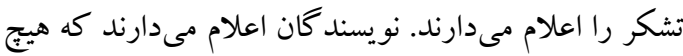
كونه تعارض منافعى در انتشار اين مقاله وجود ندارد.
Peroxisome proliferator-activated ) PPAR. $\alpha$ و و بنابراين متابوليسم ليييدها دارند، در حالى كه داروهايى مانند فنوفيبرات كه از طريق PPAR.a عمل باتراين مى كنند، سطح ترى كليسريدها را كاهش مى مهند ولى فئ تأثير كمترى بر متابوليسم قندها دارند. بههمين جهت ساخت تركيباتى كه هم بر PPAR.

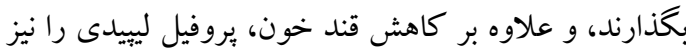

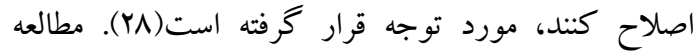
حاضر نيز بيانكر تاثير همزمان عصاره مازو بر افزايش حساسيت به انسولين و كاهش غلظت ترى كليسريد خون در مقاومت انسولينى، افزايش فعاليت ليياز حساس به هورمون در بافت جربى، منجر به افزايش هيدروليز ترىكليسريدها و در نتيجه افزايش غلظت اسيدهاى جرب إب آزاد يلاسمايى مىشود. افزايش اسيد جرب آزاد بِاسمايى يكى شاخص مهم براى تشخيص مقاومت انسولينى محيطى و كبدى است. زيرا اسيدهاى جرب آزاد مىتوانند يِيام رسانى لئى انسولين را مختل كنند. افزايش آزادسازى اسيدهاى جرب و و سيتوكينهاى ويش التهابى از بافت خربى باعث ايجاد مقاومت انسولينى در كبد و عضلات مىشود. افزايش اسيدهاى جرب آزاد و افزايش ورود آنها به كبد، باعث افزايش توليد VLDL و در نتيجه غلظت ترى كليسريد در

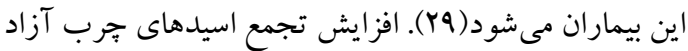

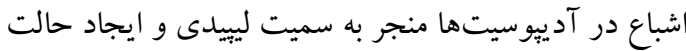
التهابى مىشودكه نه تنها حساسيت به انسولين را در آدييوسيتها، بلكه در ساير بافتها نيز تحت تأثير قرار

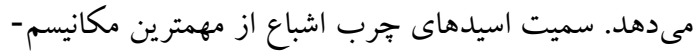
هاى بِاتوزنيكك در جاقى و ديابت نوع r محسوب

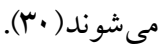

منابع 1. Jia G, Demarco VG, Sowers JR, Drive OH. Insulin resistance and hyperinsulinaemia in diabetic cardiomyopathy. HHS Public Access. 2016;12(3):144-53. 


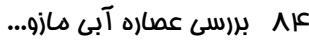

2. Ciaraldi TP. Molecular Mechanisms of Insulin Resistance: An Update Citlaly. Gac Med Mex. 2017;153(1):71-86.

3. Nicholson T, Church C, Baker DJ, Jones SW. The role of adipokines in skeletal muscle inflammation and insulin sensitivity. J Inflamm (United Kingdom). 2018;15(1):1-11.

4. Xin Y, Wang Y, Chi J, Zhu X, Zhao H, Zhao S, et al. Elevated free fatty acid level is associated with insulin-resistant state in nondiabetic Chinese people. Diabetes, Metab Syndr Obes Targets Ther. 2019;12:139-47.

5. Kimura I, Ichimura A, Ohue-Kitano R, Igarashi M. Free Fatty Acid Receptors in Health and Disease. Physiol Rev. 2020;100(1):171-210.

6. Katsuhiko Naruse, Noguchi T, Sado T, Tsunemi T, Shigetom H, Kanayama S, et al. Chemokine and Free FattyAcid Levels in Insulin-Resistant State ofSuccessful Pregnancy: A Preliminary Observation. Mediat Inflammatio. 2012;2012(1):1-6.

7. Askari SF, Azadi A, Jahromi BN, Tansaz M, Nasiri AM, Mohagheghzadeh A, et al. A comprehensive review about Quercus infectoria G. Olivier gall. Res J Pharmacogn. 2020;7(1):67-75.

8. Gholamhoseinian A, H.Fallah, F.Sharififar. Anti-hyperglycemic Activity of Four Plants Extracts Effective against Alpha Glucosidase in Normal and Diabetic Rats. J Kerman Univ Med Sci. 2009;16(1):35-44.

9. Gholamhosseinian A, Fallah H, Sharififar F, Mirtajaddini M. the inhibitory effect of some iranian plants extracts on the alpha glucosidase. Iran J Basic Med Sci. 2008;11:1-9.

10. Shiha C-C, Linb C-H, Linc W-L, Wud J-B. Momordica charantia extract on insulin resistance and the skeletal muscle GLUT4 protein in fructose-fed rats. J Ethnopharmacol. 2009;123(1):82-90.

11. Kubota N, Terauchi Y, Kubota T, Kumagai H, Itoh S, Satoh H, et al. Pioglitazone Ameliorates Insulin Resistance and Diabetes by Both Adiponectin-dependent and independent Pathways. J Biol Chem. 2006;281(13):8748-55.

12. Gholamhoseinian A, H.Fallah, F.Sharififar. Inhibitory effect of methanol extract of Rosa damascena Mill. flowerson a-glucosidase activity and postprandial hyperglycemia in normal and diabetic rats. Phytomedicine. 2009;16(1):935-41.

13. Kangani CO, Kelley DE, DeLanya JP. Newmethod for GC/FID and GC-C-IRMS analysis of plasma free fatty acid concentration and isotopic enrichment. J Chromatogr B. 2008;873(1):95-101.

14. Williamson G, Sheedy K. Effects of Polyphenols on Insulin Resistance. Nutrients. 2020;12(10):3135.

15. Governa P, Baini G, Borgonetti V, Cettolin G, Giachetti D, Magnano AR, et al. Phytotherapy in the management of diabetes: A review. Molecules. 2018;23(1):1-22.

16. Abolfathi A, Vahabzadeh Z, Mahmoodiaghdam N, Vahabzadeh D, Hakhamanesh M saeed. Effects of taurine and homocysteine on lipid profile and oxidative stress in fructose-fed rats. Sci J Kurdistan Univ Med Sci. 2017;22(3):49-59.

17. Hurst Y, Fukuda H. Effects of changes in eating speed on obesity in patients with diabetes: A secondary analysis of longitudinal health check-up data. BMJ Open. 2018;8(1):18 .

18. Stanhope KL, Schwarz JM, Keim NL, Griffen SC, Bremer AA, Graham JL, et al. Consuming fructose-sweetened, not glucose- sweetened, beverages increases visceral adiposity and lipids and decreases insulin sensitivity in overweight/obese humans. J Clin Invest. 2009;119(5):1322-34.

19. Kojta I, Chacinska M, Błachnio-Zabielska A. Obesity, Bioactive Lipids, and Adipose

هجله علمى دانشَاه علوم بِرشكى كردستان / دوره بيست و شش / فروادين و ا(ديبرشت م.ع|| 
Tissue Inflammation in Insulin Resistance. Lancet. 2020;12(1305):1-19.

20. Belkina AC, Denis GV. Obesity genes and insulin resistance. Current Opinion in Endocrinology. 2010; 17(5): 472-7.

21. Malin SK, Niemi N, Solomon TPJ, Haus JM, Kelly KR, Filion J, et al. Exercise training with weight loss and either a high- or low-glycemic index diet reduces metabolic syndrome severity in older adults. Ann Nutr Metab. 2012;61(2):135-41.

22. Saini R, Patil SM. Anti-Diabetic Activity Of Roots Of Quercus Infectoria Olivier In Alloxan Induced Diabetic Rats. Int J Pharm Sci Res. 2012;3(4):1318-21.

23. Sathya Bhama CV, Balaji S, Seethalakshmi A. Analysis of the degree of insulin resistance in post menopausal women by using skin temperature measurements and fasting insulin and fasting glucose levels: A case control study. Journal of Clinical and Diagnostic Research. 2012; 6(10): 1644-7.

24. Rifahil N. Tietz Textbook of Clinical Chemistry and Molecular Diagnosis. Sixth ed. United States of America: Elsevier, 2018. 1160-1200.

25. Abdina AA, Baalash AA, Hamooda HE. Effects of rosiglitazone and aspirin on experimental model of induced type 2 diabetes in rats: focus on insulin resistance and inflammatory markers. J Diabetes Complications. 2010;24(1):168-78.

26. Ohnogi H, Hayami S, Kudo Y, Deguchi S, Mizutani S, Tatsuji Enoki, et al. Angelica keiskei Extract Improves Insulin Resistance and Hypertriglyceridemia in Rats Fed a HighFructose Drink Hiromu. Biosci Biotechnol Biochem. 2012;76(5):928-32.

27. Gholamhoseinian A, Shahouzehi B, Joukar S. Effect of Quercus infectoria and Rosa damascena on Lipid Profile and Atherosclerotic Plaque Formation in Rabbit Model of Hyperlipidemia. pakistan J Biol Sci. 2012;15(1):27-33.

28. Botta M, Audano M, Sahebkar A, Sirtori CR, Mitro N, Ruscica M. PPAR agonists and metabolic syndrome: An established role? Int J Mol Sci. 2018;19(4):2-21.

29. Meshkani R, Adeli K. Hepatic insulin resistance, metabolic syndrome and cardiovascular disease. Clin Biochem [Internet]. 2009;42(13-14):1331-46.

30. Kennedy A, Martinez K, Chuang C-C, LaPoint K, McIntosh M. Saturated Fatty AcidMediated Inflammation and Insulin Resistance in Adipose Tissue: Mechanisms of Action and Implications. J Nutr. 2009;139(1):1-4.

هجله علمى دانشكاه علوم يِشكى كردستان / دوره بيست و شش / فرودين و ارديبرشت م.ع|| 